\title{
Study on Groundwater Quality Using Geographic Information System (GIS), Case Study: Ardabil, Iran
}

\author{
Redvan Ghasemlounia ${ }^{a^{*}}$, Nasim Sedaghat Herfeh ${ }^{\mathrm{b}}$ \\ ${ }^{a}$ Ph.D. in Hydraulic and Water Resources, Istanbul Technical University, Turkey. \\ ${ }^{b}$ Ph.D. Candidate in Mechanical Engineering of Biosystems, Tehran University, Iran.
}

Received 23 July 2017; Accepted 26 September 2017

\begin{abstract}
This study involves the analysis of water resources pollution data using Geographic Information System (GIS), which is a subset of the purposes such as: study on the status (situaion) of the aquifer, the natural and man-made effects on aquifer quality, evaluation and investigation of quality monitoring results of Ardabil aquifer, study on quality limitations by comparing the results of analysis of wet and dry seasons from water resources with selected standards. Therefore, samples were collected from76 wells, in this region, for the purpose of the aquifer water quality assessment, identification of changing process of pollution and statistical analysis of quality parameters included NTU, TDS, Nitrates and Chloride. Afterwards, maps for each parameter were produced in the geographic information system (GIS) using scientific methods. Thereupon, situation and condition of water quality was measured by quality mapping index of NSFWQ and was applied for whole the basin. This maps and database, which were created by the software, provide and offer an obvious view of what happened in the study area. As a result, it could be applied for a better management of these water resources and planning to prevent further pollution, by relevant organizations.
\end{abstract}

Keywords: Geographic Information System (GIS); Ground Water; Ardabil; Aquifer; NSFWQ.

\section{Introduction}

Water is the most essential element of life. More than 70 percent of Earth's surface is covered with water, however only $3 \%$ of this water is available as fresh water. Another remarkable point, the major portion of fresh water is found in groundwater or in the form of icecaps and glaciers. Therefore, monitoring, controlling and management of water quality in aquifers, as the main sources of fresh water, are important facts. According to the assessment of scientists and researchers, in the 21 st century, amount of world water reserves will be reduced due to the global climate change, which will lead to the freshwater shortage in most countries. Groundwater is the world's largest freshwater source after glaciers and it is used.in developed countries, mostly. It is because of the better quality in the case of the bacteria than the other freshwater resources. Thereupon, water-related disease outbreaks are minimized using these kind of water resources. Despite this, with increasing of population, agricultural and industrial activities, these water resources are facing with the risk of pollution and it caused this precious resource been unusable. The evacuation of thousands cubic meters of industrial and domestic wastewaters and also, drainage water of agricultural lands into the surface and groundwater resources, caused to increasing of pollution of these resources and, finally, it has been led to the creation of environmental disasters. Since the significant portion of the pollutions, which created on the surface of the basin, enters into its aquifers, groundwater pollution has increased considerably. Therefore, in recent decades, significant efforts has been done to

* Corresponding author: rghasemlounia@gmail.com

DOI: http://dx.doi.org/10.21859/cej-030914

$>$ This is an open access article under the CC-BY license (https://creativecommons.org/licenses/by/4.0/).

(C) Authors retain all copyrights. 
preserve the clean aquifers and to revitalize the polluted aquifer. Cost of protection of clean aquifers is much less than the revitalization cost of polluted aquifers. On the other hand, usage of groundwater has been highly popular in Iran, because of the shortage of surface waters. Nowadays, as in the past, an important part of the required water for agricultural and urban use is provided and supplied by groundwaters. According to this, one could say that the major goal of theaquifer quality management is to equitable allocation of water between consumers and determine the amount of refinement and filtration of entering pollutants to aquifer. This management is to prevent exceeding standart limitis of quality variations of concentration in control points and also, to minimizing the filtration costs. Identifying the sources of pollution, prevention, controlling and reducing aquifer pollution is essential in order to prevent and control of increasing pollution in aquifers and to reducing the pollution of them.

Reviewing last literatures and articles shows that various studies and researches have been done about groundwater quality. Some of them have studied on only physical and chemical parameters, while some other researchers studied the parameters in combined mode and bacteriological situation. Furthermore, some studies are available about quality and chemical components of water. Ahmadi and Aberoumand (2009) used geographic information system (GIS) for their research on pollution vulnerability of Khash palin-aquifer, eastern Iran [1]. Asghari Moghadam et al. (2015) applied GQI and FGQI methods for the assessment of groundwater quality in Mehraban Plain according to WHO and ISIRI standards. They used ten affective chemical parameters with high concentrations in groundwater, and high efficiency for their purpose and compared with WHO and ISIRI standards [5]. Asadi et al. (2017) studied on vulnerability assessment of urban groundwater resources to nitrate and selected the aquifer of Mashhad city in Iran, for their case study [7]. Nas and Berktay (2008) studied on the groundwater quality of Konya city located in the central part of Turkey [19]. They used GIS for their research and took samples from 177 wells in study area. Fritch et al. (2000) developed an approach to evaluate the susceptibility of groundwater of their study area, which was located in north-central Texas, to contamination [9]. Gharbia et al. (2016) worked on groundwater evaluation in Gaza Strip area using GIS based geostatistical algorithms [10]. Jahanshahi et al. (2014) investigated the suitability of the plain aquifer water for agricultural and drinking uses with the Wilcox and Schoeller Standards for their case study, Shar-Babak aquifer [13]. Jha et al. (2015) investigated an attempt to integrate CWQI and GIS based mapping technique to derive a reliable, simple and useful output for water quality monitoring in coastal environment [14].

Groundwater quality mapping using geographic information system (GIS) was a research title that Balakrishnan et al. were worked on [3]. They selected Gulbarga city as the case study area for the study. Mahalingam et al. (2014) prepared the distribution map of physio-chemical parameters and groundwater quality zones of Mysore city [16]. Mendes and Ribeiro (2010) worked on a topic entitled Nitrate probability mapping in the northern aquifer alluvial system of the river Tagus (Portugal) using Disjunctive Kriging [17]. Ouyang (2005) used Twenty-two stations for monitoring physical, chemical, and biological parameters, located at the main stem of the lower St. Johns River in Florida. He used the PFA technique to identify important water quality parameters [20]. Remesan and Panda (2007) studied on Kapgari watershed groundwater quality mapping using GIS [21]. They performed chemical analysis on groundwater samples, which were taken from various locations within the catchment at different times. Spatial Analysis of Groundwater Quality Using Geographic Information System for Karur district was the topic that Krishnaraj et al. studied about [15]. They selected 100 water quality monitoring stations for their work, totally. Mahalingam et al. (2014) worked on Mysore city's groundwater quality using GIS techniques [16]. Subramani et al. (2012) studied on Coonoor Taluk's groundwater quality using GIS, which is located in Nilgiri district, India [22]. Maynar Babu et al. (2014) determined water quality parameters for drinking water standards using standard water quality procedures and prepared spatial distribution maps in Arc GIS environment [23]. Yang and Jin (2010) investigated the use of spatial regression to evaluate the impacts of watershed characteristics on stream NO3NO2-N concentration in the Cedar River Watershed, Iowa [25]. Classical statistics, geostatistical method combined with GIS technique were then used by Zhou et al. (2011) to analyze the spatial variability and distribution of GWL and groundwater chemical properties [26].

The thing distinguishes this study with others, is the study on aquifer in both wet and dry seasons and use of the general quality zonation index (NSFWQ). The obtained results are different for each season. In addition, this study depicts a clearer status of the aquifer. The main objective of this study is to investigate and determine the groundwater pollution and the efficient and optimal use of these kind of water resources. Saving in time and money is the most important capability of geographic information system (GIS). First step of groundwater resources evaluation for a vast area is collecting and gathering of required data and then analyzing them. Due to the unique capability of Geographic Information System (GIS) in preparing and analyzing of large data in a wide area, and getting result from these data, this technology was selected for this study. The main objectives of this research could be summarized as follows, generally:

1. Investigation and evaluation of the current status of aquifer, identification of the physical and chemical properties of aquifer, sources and potentials of pollution in aquifer.

2. Statistical analysis of quality parameters including: turbidity, nitrate, chloride and dissolved solids in this area.

3. Evaluation of water quality monitoring results of aquifer, documentation of all obtained information in the form of maps and tables, which have been prepared in GIS. 
4. Study on the the qualitative constraints for various uses and comparison of results from the analysis of the wet and dry seasons of water resources with selected standards such as EPA and WHO.

5. Using of zoning quality index of NSFWQ (National Sanition Fundation Water Quality Index), study on the water quality situation and conditions in the basin.

6. Providing practical and executive plans for preventing, controlling and reducing pollution in aquifer and providing appropriate suggestions.

\section{Materials and Methods}

Having an area of 17953 square kilometer, Ardabil province is located between 37.45- 39.42 northing latitudes and 47.30-48.55 easting longitudes at northwest of Iran. The population of this province is about 1228155, whilst the population for Ardabil city, the provincial capital, is more than 418262. Province and aquifer location and borders are shown in Figure 1.

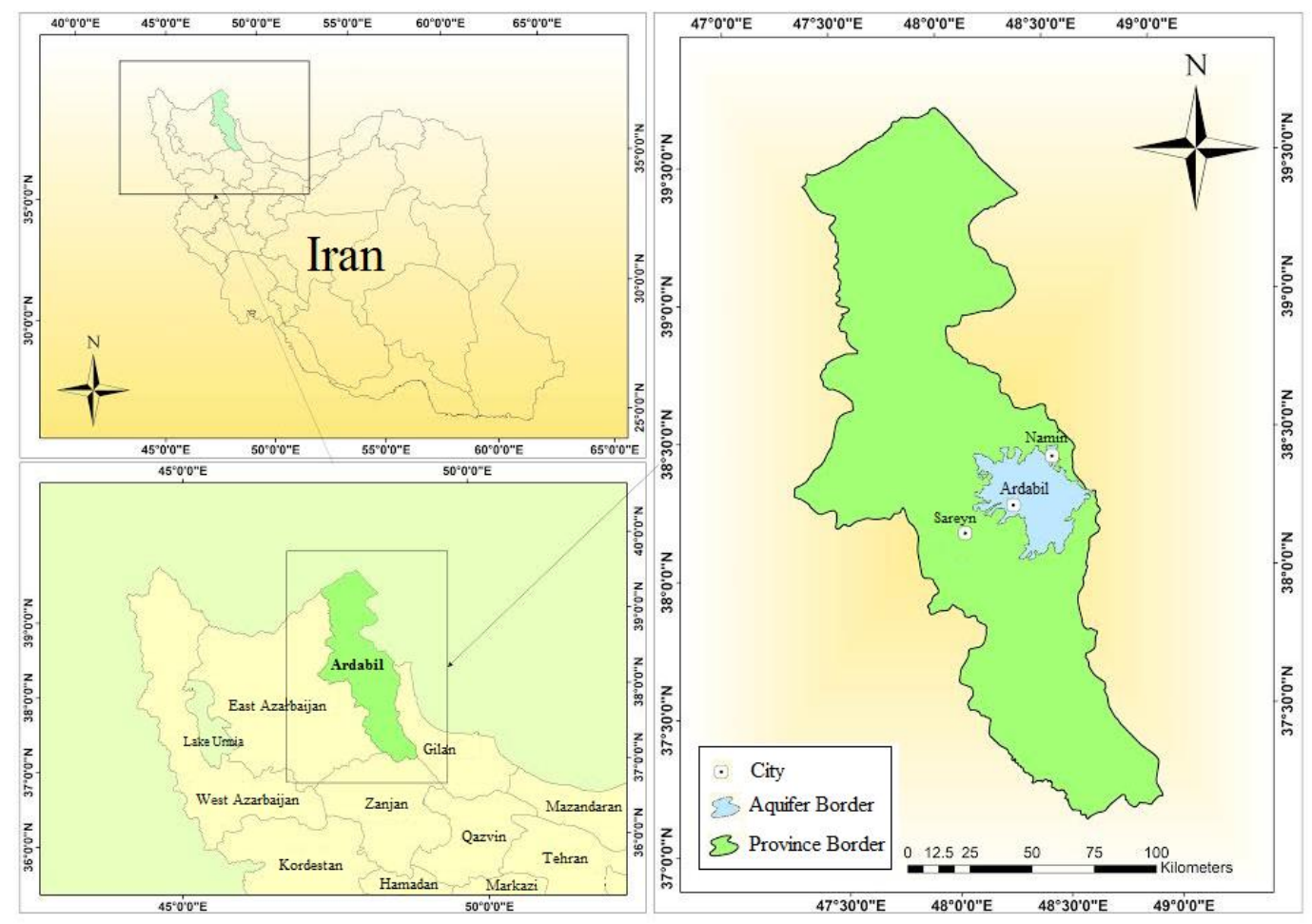

Figure 1. Ardabil Province and Aquifer Location and Borders.

Due to Geographic Information System's (GIS) specific features and capabilities, it is a very helpful and important tool. This system has the capability of collecting, storing and analyzing the various parameters, concurrently and needs a short time to providing and presenting geospatial data. Low cost, high computing accuracy, using complicated analytical functions, editing capabilities and fast data updating features, modeling and reporting in multiple forms are the other features of GIS. In general, by using of this tool for aquifers, hydrogeological and groundwater pollution cases, the database, groundwater level maps, groundwater base maps, investigation and zoning of pollution about these resources can be prepared for manage them, when required. In order to statistical analysis of measured parameters for evaluation of the Ardabil aquifer pollution, Excel and SPSS softwares have been used in this study. It has been avoided to describing and presenting of all steps of this work due to the large number of stations, high volume of information and numerous phases and steps of software operation. 


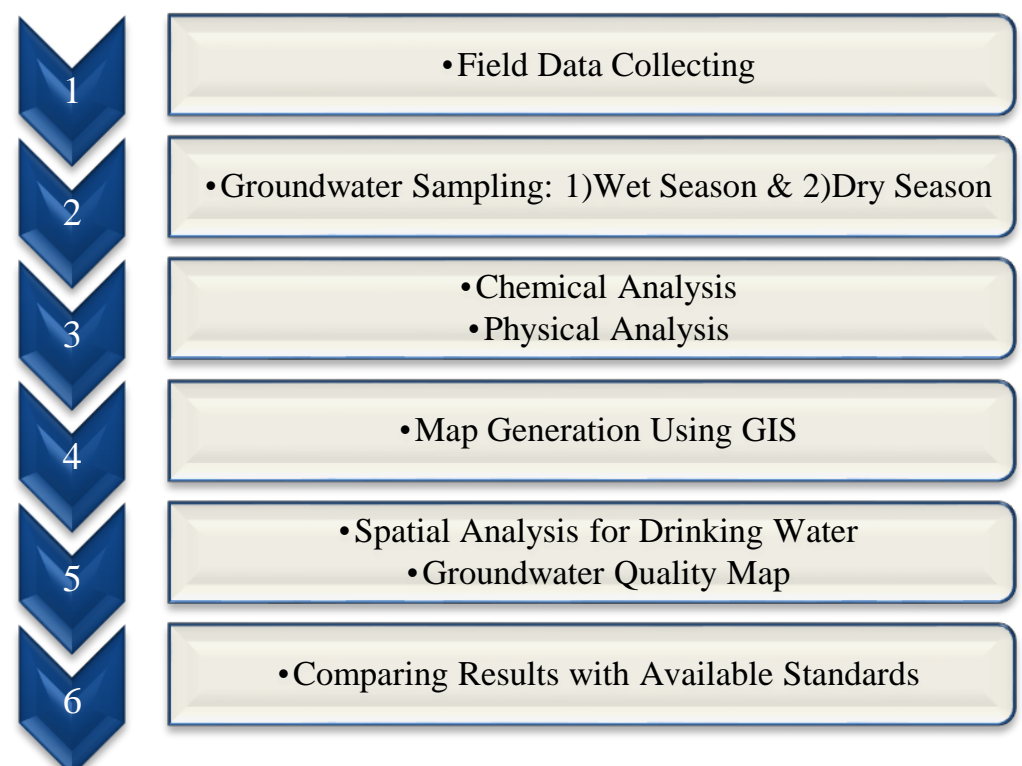

Figure 2. Flow chart of study.

For the aim of the Ardabil aquifer water quality assessment, identification of changing process of pollution and statistical analysis of quality parameters included NTU, TDS, Nitrates and Chloride, samples were collected from76 wells, in this region. Coordinates of these selected wells for sampling are presenting in Table 1.

Table 1. Coordinates of selected wells in Ardabil aquifer.

\begin{tabular}{|c|c|c|c|c|c|c|c|c|c|c|c|c|c|c|}
\hline \multirow{2}{*}{$\begin{array}{l}\text { Well } \\
\text { No. }\end{array}$} & \multicolumn{2}{|c|}{ Coordinates } & \multirow{2}{*}{$\begin{array}{l}\text { Well } \\
\text { No. }\end{array}$} & \multicolumn{2}{|c|}{ Coordinates } & \multirow{2}{*}{$\begin{array}{l}\text { Well } \\
\text { No. }\end{array}$} & \multicolumn{2}{|c|}{ Coordinates } & \multirow{2}{*}{$\begin{array}{l}\text { Well } \\
\text { No. }\end{array}$} & \multicolumn{2}{|c|}{ Coordinates } & \multirow{2}{*}{$\begin{array}{l}\text { Well } \\
\text { No. }\end{array}$} & \multicolumn{2}{|c|}{ Coordinates } \\
\hline & $\mathbf{X}$ & $\mathbf{Y}$ & & $\mathbf{X}$ & $\mathbf{Y}$ & & $\mathbf{X}$ & $\mathbf{Y}$ & & $\mathbf{X}$ & $\mathbf{Y}$ & & $\mathbf{X}$ & $\mathbf{Y}$ \\
\hline 1 & 262447 & 4239188 & 17 & 261931 & 4238733 & 32 & 272154 & 4231648 & 47 & 269747 & 4243133 & 62 & 280373 & 4255698 \\
\hline 2 & 486046 & 4247912 & 18 & 268206 & 4241348 & 33 & 260255 & 4252343 & 48 & 285075 & 4234626 & 63 & 275997 & 4250235 \\
\hline 3 & 273852 & 4217897 & 19 & 271372 & 4241658 & 34 & 283485 & 4235188 & 49 & 290910 & 4239308 & 64 & 273402 & 4246238 \\
\hline 4 & 258387 & 4245483 & 20 & 282045 & 4248094 & 35 & 260150 & 4251159 & 50 & 275051 & 4233992 & 65 & 269522 & 4245242 \\
\hline 5 & 284876 & 7239127 & 21 & 281566 & 4253050 & 36 & 259889 & 4232647 & 51 & 278616 & 4237459 & 66 & 276971 & 4244523 \\
\hline 6 & 280373 & 4255689 & 22 & 268897 & 4222401 & 37 & 272168 & 4247661 & 52 & 273541 & 4246380 & 67 & 269330 & 4247492 \\
\hline 7 & 267839 & 4253621 & 23 & 269172 & 4229430 & 38 & 262452 & 4246762 & 53 & 275092 & 4255143 & 68 & 268550 & 4248183 \\
\hline 9 & 257095 & 4236478 & 25 & 277589 & 4227671 & 40 & 260780 & 4245702 & 55 & 257019 & 4230059 & 70 & 273930 & 4258311 \\
\hline 10 & 256502 & 4238550 & 26 & 274196 & 4223852 & 41 & 260310 & 4251030 & 56 & 266474 & 4234511 & 71 & 261696 & 4233234 \\
\hline 11 & 265971 & 4240820 & 27 & 260490 & 4237794 & 42 & 259997 & 4232767 & 57 & 267773 & 4235938 & 72 & 261785 & 4232409 \\
\hline 12 & 262198 & 4234864 & 28 & 264442 & 4247599 & 43 & 268440 & 4238056 & 58 & 252905 & 4242751 & 73 & 262297 & 4233019 \\
\hline 13 & 262490 & 4235234 & 29 & 265197 & 4250695 & 44 & 259830 & 4232792 & 59 & 254543 & 4235386 & 74 & 271885 & 4245290 \\
\hline 14 & 263621 & 4240016 & 30 & 262357 & 4239785 & 45 & 277583 & 4235042 & 60 & 267839 & 4253621 & 75 & 290910 & 4239308 \\
\hline 15 & 262400 & 4239219 & 31 & 272338 & 4249458 & 46 & 260569 & 4233853 & 61 & 272634 & 4247226 & 76 & 272742 & 4246739 \\
\hline 16 & 261451 & 4238392 & & & & & & & & & & & & \\
\hline
\end{tabular}

The distribution and position of selected wells in this region is displayed in Figure 3. 

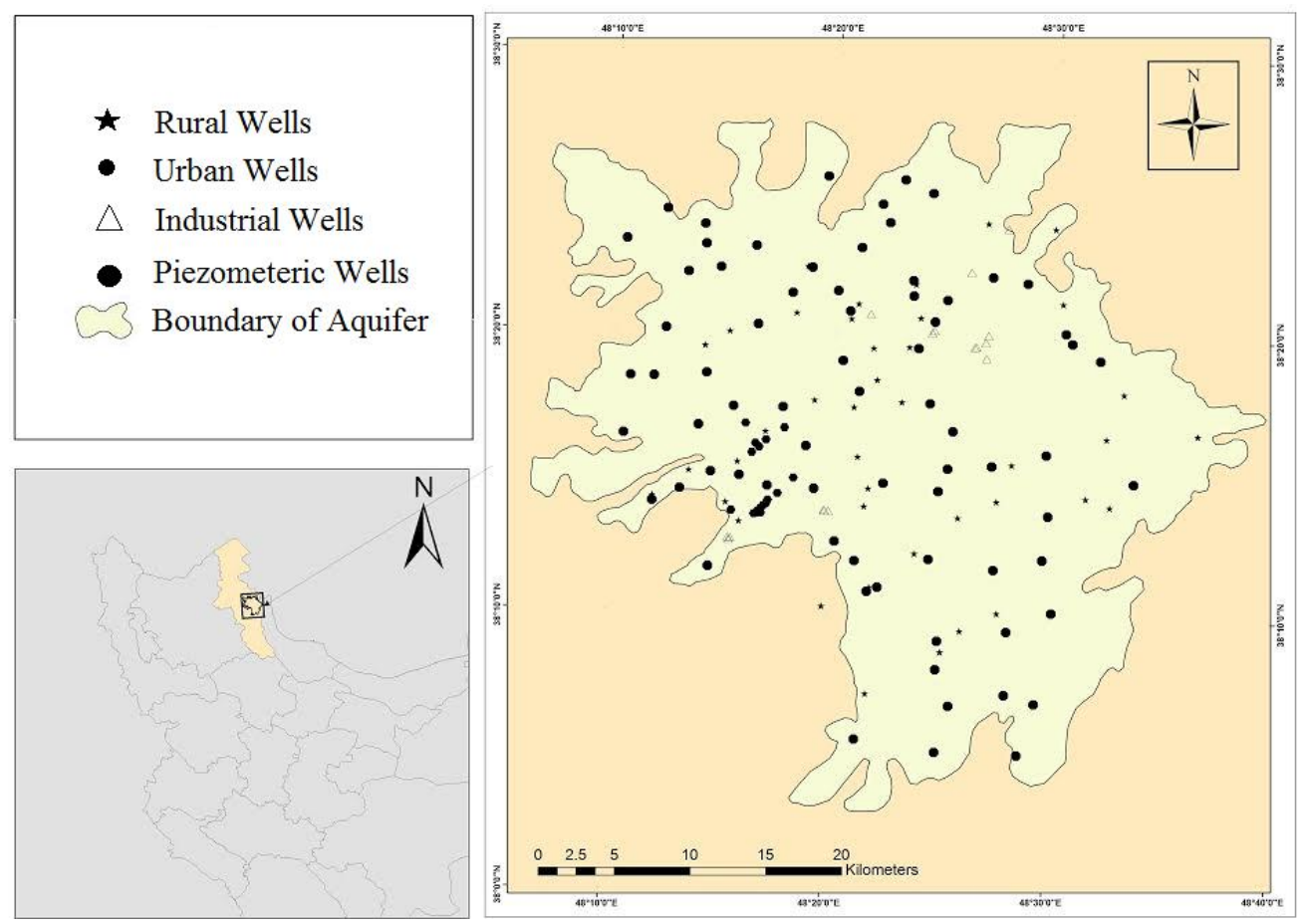

Figure 3. Distribution of selected wells

\subsection{Guidelines for Drinking Water Quality}

The purpose of drinking water quality guidelines by the World Health Organization (WHO) is to use them for codifying national standards in different countries, that if this is done properly, healthy drinking water will be provided by eliminating or reducing the concentration of harmful pollutants for human health. Therefore, providing of safe drinking water and trying to achieve high-quality drinking water is an essential matter. The best solution for providing safe drinking water is conservation of available water resources and preventing them from getting polluted. This preventative actions are more preferable than the treatment methods, which used for purification of polluted water. Based on the results of analysis of ground water samples, quality of these water resources was evaluated. For this purpose, some physical and chemical parameters and distribution of these parameters were prepared as relevant maps and then compared. Finally, the quality of these waters were compared with available standards for different uses such as the standard that provided by the World Health Organization WHO (2008) and EPA (2009).

Table 2. Standard of the World Health Organization WHO (2008)

\begin{tabular}{cc}
\hline Parameter & WHO $(\mathbf{m g} / \mathbf{L})$ \\
\hline Total Dissolved Solids (TDS) & 500 \\
Hardness (TH) & 500 \\
Chloride $\left(\mathrm{Cl}^{-}\right)$ & 200 \\
Nitrate $\left(\mathrm{NO}_{3}^{-}\right)$ & 40 \\
\hline
\end{tabular}

Standards which selected and used for this study are the latest and most practical standards that have been provided by Department of Environment of Iran, United States Environmental Protection Agency (EPA), European Environment Agency (EEA), World Health Organization (WHO) and standards of other countries. One of the important points in order to protect these water resources is determining their quality condition. In the past, the quality of a water resource was measured based solely on the amount of physical, chemical and biological parameters of it.

In the present study, situation and condition of water quality is measured by using NSFWQI quality zoning index. National Sanitation Foundation Water Quality Index of United States (NSFWQI) was developed in 1970 with the support of the United States National Sanitation Foundation. This method was adjusted based on providing a questionnaire, which had been filled by highly qualified professionals and experts of this field in United States of America. Using the questionnaire's responses, a curve was drawn for each of parameters. Sub-indices of each parameter could be determined using theses curves. Equation (1) is used for calculating NSFWQ index.

$N S F W Q I=\sum_{i=1}^{n} W_{i} I_{i}$ 
Where, $\mathrm{I}_{\mathrm{i}}$ is sub-indices of each parameter, $\mathrm{W}_{\mathrm{i}}$ is weighting factor of each parameter and $\mathrm{n}$ is number of parameters in the index calculation system. Standard curves are used for calculating sub-indices and weighting factors are obtained according to the number of parameters involved in the index calculation. The used final weighting factor in this index is provided in Table 4. Thus, if one of the sub-indices is in poor condition, then the overall index will reflect the poor condition. Therefore, to calculating of NSFWQI quality index, according steps should be done:

a) Providing qualitative information including:

1) $\left.\left.\left.\left.\mathrm{DO}, 2) \mathrm{BOD}_{5}, 3\right) \mathrm{NO}_{3}, 4\right) \mathrm{PO}_{4}, 5\right) \mathrm{SS}, 6\right) \mathrm{pH}$, 7) Turbidity, 8) Fecal Coliform, 9) TDS.

b) Calculating of sub-index of each parameter from related curves.

c) Determination of weighting factor of each parameter according to number of parameters, which have the qualitative information.

d) Calculation of the final index, using equation 1 .

The amount of NSFWQI is reduced by increasing water pollution. This index has a value between 0 and 100 and is graded according to Table 3 .

Table 3. Water quality classification according to NSFWQI

\begin{tabular}{cc}
\hline Index amount & Water Quality Description \\
\hline $91-100$ & Excellent \\
$71-90$ & Good \\
$51-70$ & Medium \\
$26-50$ & Unsuitable \\
$0-25$ & Very unsuitable \\
\hline
\end{tabular}

Table 4. Weighting Factor of NSFWQI

\begin{tabular}{cc}
\hline Parameter & Weighting factor \\
\hline DO & 0.17 \\
Fecal Coliform & 0.16 \\
pH & 0.11 \\
BOD5 & 0.11 \\
NO3 & 0.10 \\
PO4 & 0.10 \\
T & 0.10 \\
Turbidity & 0.08 \\
TS & 0.07 \\
\hline
\end{tabular}

\section{Significant Recommendations on Sampling}

Detailed recommendations about the methods used for sampling from different water resources are presented, which should be applied. The purpose of sampling is to obtain a small portion of the water, which is re-presenter of the real characteristics of the main resource. The most important fundamental factors to achieve this goal include:

a) Sampling points, sampling time, sampling frequency and maintain the integrity of the sample until the sampled water being tested in the laboratory.

b) For sampling from resources such as: wells, reservoirs, water supply network and channels, moment sampling should be used for chemical, physical and bacteriological tests.

c) A moment sample only represents the existing situation and condition at place and time of sampling.

Increasing the number of sampling points can provide more information about the status of the groundwater if chosen 
properly. The most important factor in choosing the number of sampling points is identifying or predicting of spatial variations of groundwater quality. The number of sampling points should be more, if spatial variations of groundwater quality is high. United States Geological Survey (USGS) suggests that the minimum number of sampling points should be considered as 30 stations in majority of cases. In this study, selection of stations and their distribution was carried out based on random sampling. Selected urban, rural and industrial wells for sampling were adopted by consulting with numerous experts.

\section{Results and Discussion}

\subsection{Turbidity of Study Area}

As it is clear from Table 5, the average turbidity is equal to 5.29 NTU for wet season and 3.15 NTU for dry season. The minimum of this parameter for wet and dry seasons is equal to zero in most of stations and the maximum value of this parameter is 175 NTU for wet season in Shourabil stations (Stations No:71, 72 and 73). By comparing the results in both wet and dry seasons, it is concluded that the maximum turbidity occurred in wet season. The reason for this may be as a result of increasing in rainfall (precipitation) and the probability of infiltration of turbidity factor into the groundwater.

Table 5. Statistical analysis of turbidity values in the study area.

\begin{tabular}{cccccccccccc} 
& \multicolumn{3}{c}{ Wet Season } & \multicolumn{4}{c}{ Dry Season } & \multicolumn{3}{c}{ Standard Values } \\
\hline \multirow{2}{*}{ Pollutant } & Min. & Max. & Mean & S.D & Min. & Max. & Mean & S.D & EPA & WHO & EU \\
\hline \multirow{2}{*}{ Turbidity (NTU) } & 0 & 175 & 5.29 & 24.23 & 0 & 3.15 & 0.071 & 0.412 & $0.5-5$ & 5 & 4 \\
\hline
\end{tabular}

Figures 4 and 5. show the turbidity distribution maps for wet and dry seasons in study area, respectively.

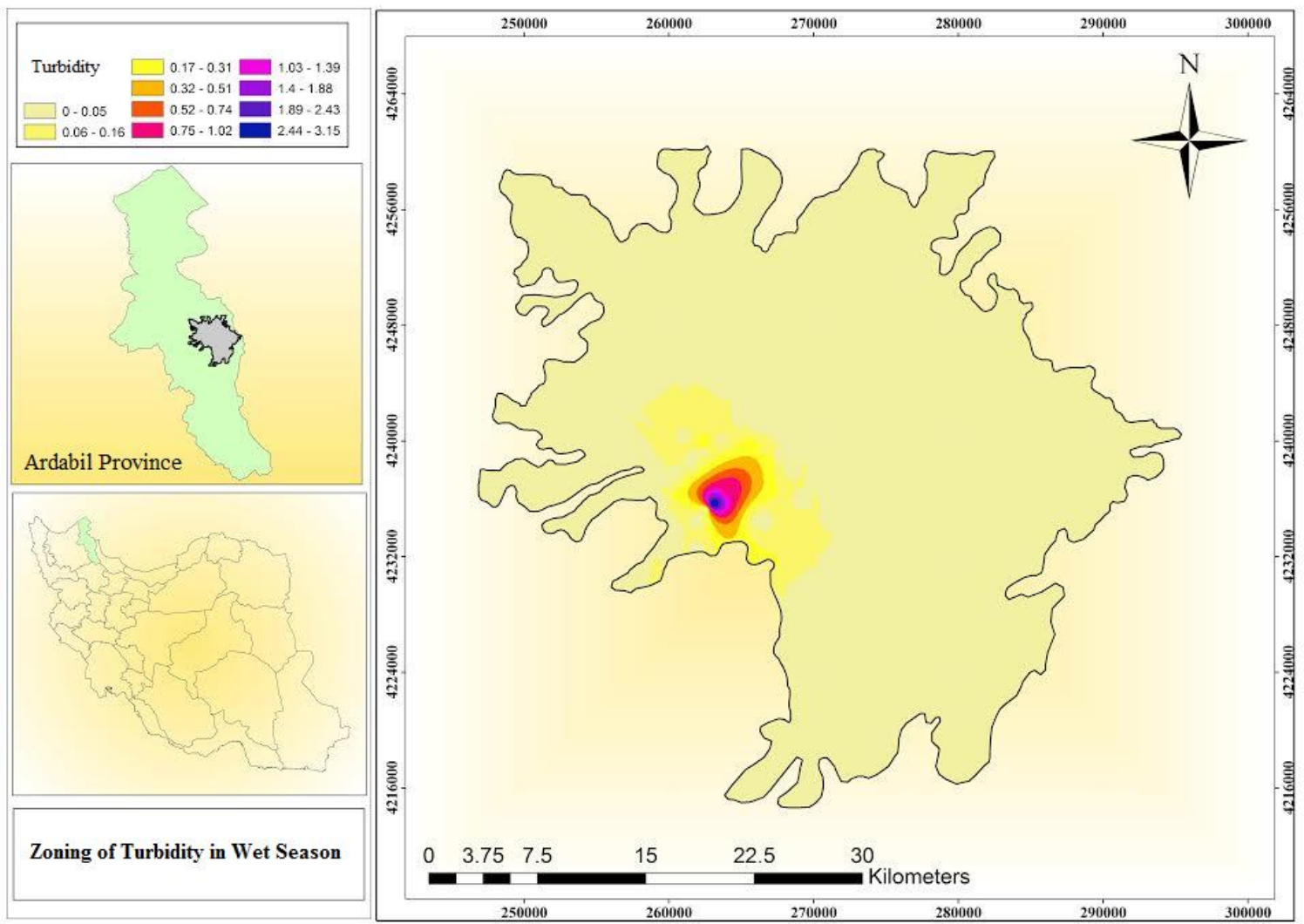

Figure 4. Turbidity distribution map in study area (wet season) 

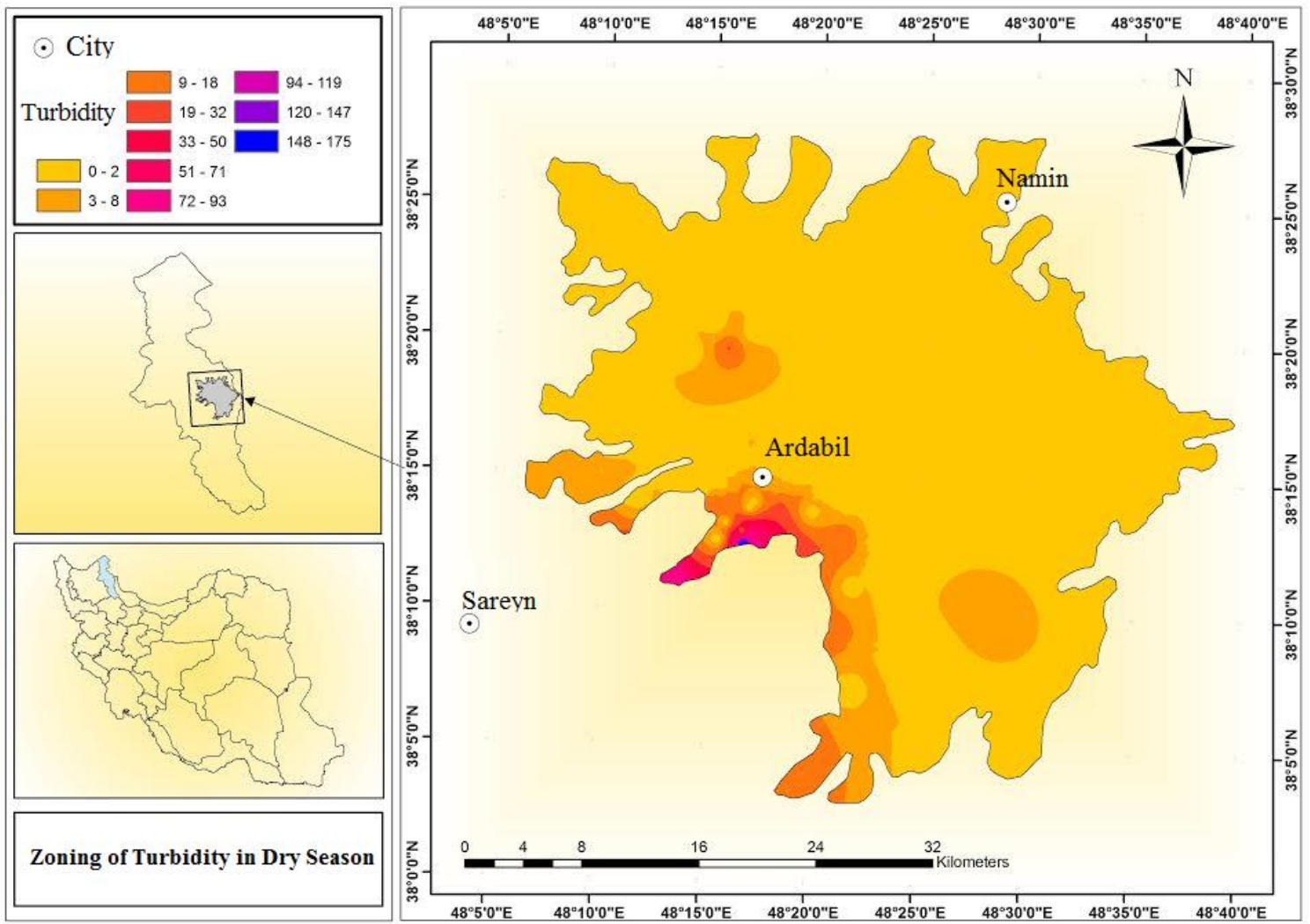

Figure 5. Turbidity distribution map in study area (dry season)

As mentioned before, the maximum allowed turbidity for drinking purposes is 5 NTU. By comparing the results, it is found that in some cases and zones, the allowable limit is exceeded. Especially during the wet season sampling, which was conducted in May, it is obvious that the rainfall in this season causes to increasing in turbidity.

\subsection{Total Dissolved Solids (TDS) of Study Area}

As it is shown in Table 6, the average of TDS for study area is equal to $1117.12 \mathrm{mg} / \mathrm{l}$ and $1093.93 \mathrm{mg} / \mathrm{l}$ for wet and dry season, respectively. The minimum value for this parameter is related to the wet season of Khalil Abad station (Station No:25) with $92 \mathrm{mg} / \mathrm{l}$. Maximum value for total dissolved solids in the study area is equal to $14980 \mathrm{mg} / \mathrm{l}$ for wet season, which was measured from Solout station (Station No:53). Analysis the results of this parameter shows that the concentration of total dissolved solids in wet season is more than the concentration of this parameter in dry season.

Figures 6 and 7. represent the measured total dissolved solids (TDS) distribution in study area. The TDS value for wet and dry seasons, standard values of TDS for EPA, WHO and EU are shown as Table 6.

Table 6. Statistical analysis of TDS (mg/l) values in the study area

\begin{tabular}{cccccccccccc} 
& \multicolumn{4}{c}{ Wet Season } & \multicolumn{4}{c}{ Dry Season } & \multicolumn{3}{c}{ Standard Values } \\
\hline \multirow{2}{*}{ Pollutant } & Min. & Max. & Mean & S.D & Min. & Max. & Mean & S.D & EPA & WHO & EU \\
\hline TDS (mg/l) & 92 & 14980 & 1117.1 & 1541.6 & 148 & 3716 & 1011.93 & 643.65 & 500 & 1000 & - \\
\hline
\end{tabular}




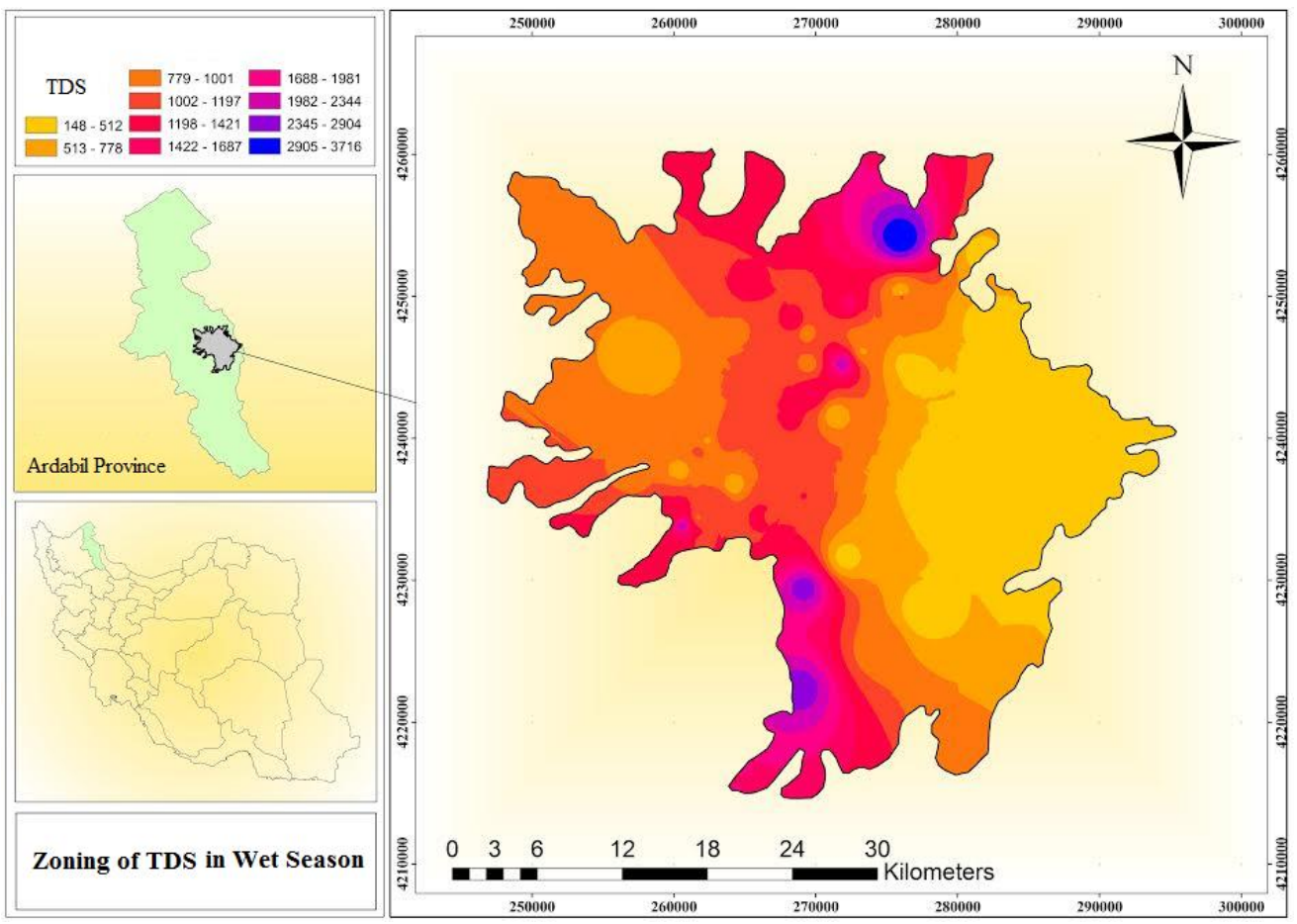

Figure 6. TDS distribution map in study area (wet season)

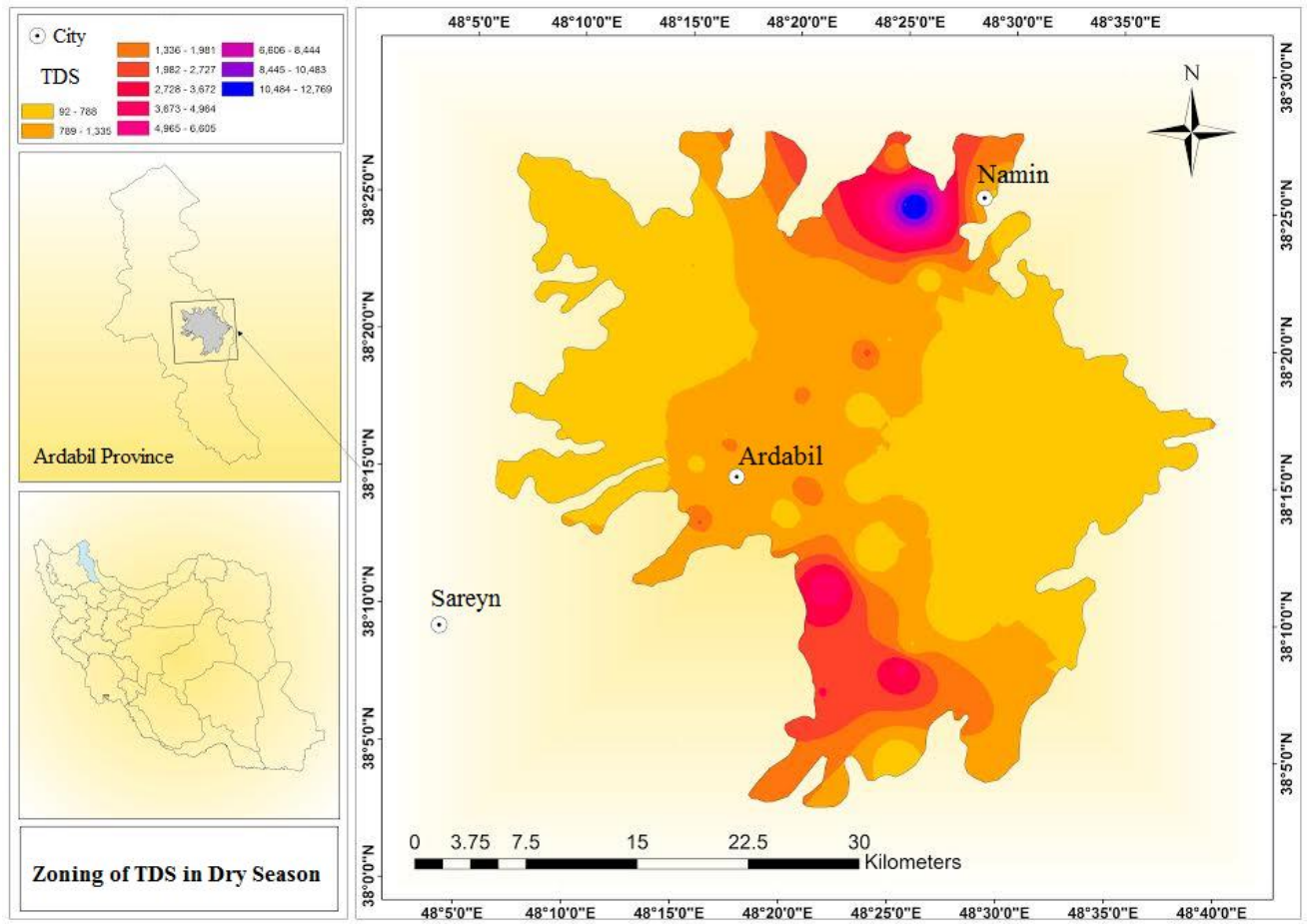

Figure 7. TDS distribution map in study area (dry season)

Measured total dissolved solids (TDS) of samples from all stations in the study area, indicates that the amount of TDS is higher than the drinkink water standards at some of the stations. For example, TDS value is 14 times higher than WHO drinking water standards for TDS in Solout station (Station No:53), which was equal to $14980 \mathrm{mg} / \mathrm{l}$.

\subsection{Chloride of Study Area}

As shown in Table 6, the average of Chloride parameter for wet season is equal to $190.34 \mathrm{mg} / \mathrm{l}$ in selected study area. This parameter has a value equal to $187.25 \mathrm{mg} / \mathrm{l}$ for dry season of study area. Minimum value for Chloride is related to the Khalil Abad station (Station No:25) for wet season and equal to $8.9 \mathrm{mg} / \mathrm{l}$, while the maximum value of this parameter is equal to $2011.7 \mathrm{mg} / \mathrm{l}$, which was measured at Solout station (Station No:53) in wet season. Presented average results show that the concentration of Chloride in wet season is higher than dry season. As shown in Figure 8, it is obvious that the Chloride concentration in North-East part of the study area is higher than allowed maximum standards. While in dry 
season, the concentration of Chloride is higher than allowed maximum standards in North-East and East part of the selected area (Figure 9).

Table 7. Statistical analysis of Chloride (mg/l) concentrations in the study area.

\begin{tabular}{cccccccccccc} 
& \multicolumn{4}{c}{} & \multicolumn{4}{c}{ Wet Season } & & & \multicolumn{3}{c}{ Dry Season } & & \multicolumn{2}{c}{ Standard Values } \\
\hline Pollutant & Min. & Max. & Mean & S.D & Min. & Max. & Mean & S.D & EPA & WHO & EU \\
\hline Chloride (mg/l) & 8.9 & 2011.7 & 190.34 & 253.5 & 20.9 & 1077.1 & 187.25 & 168.43 & 250 & - & 250 \\
\hline
\end{tabular}

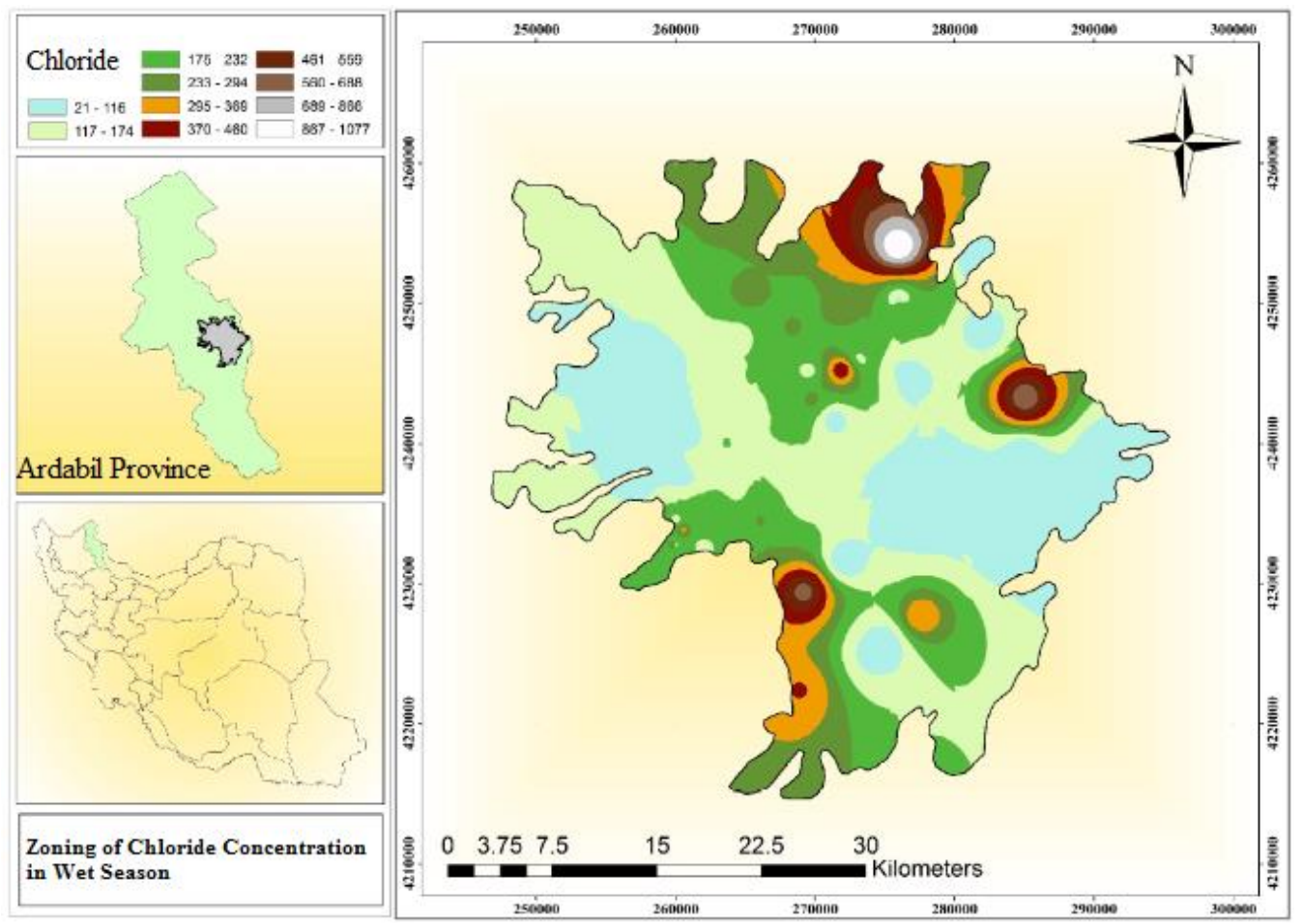

Figure 8. Chloride distribution map in study area (wet season)

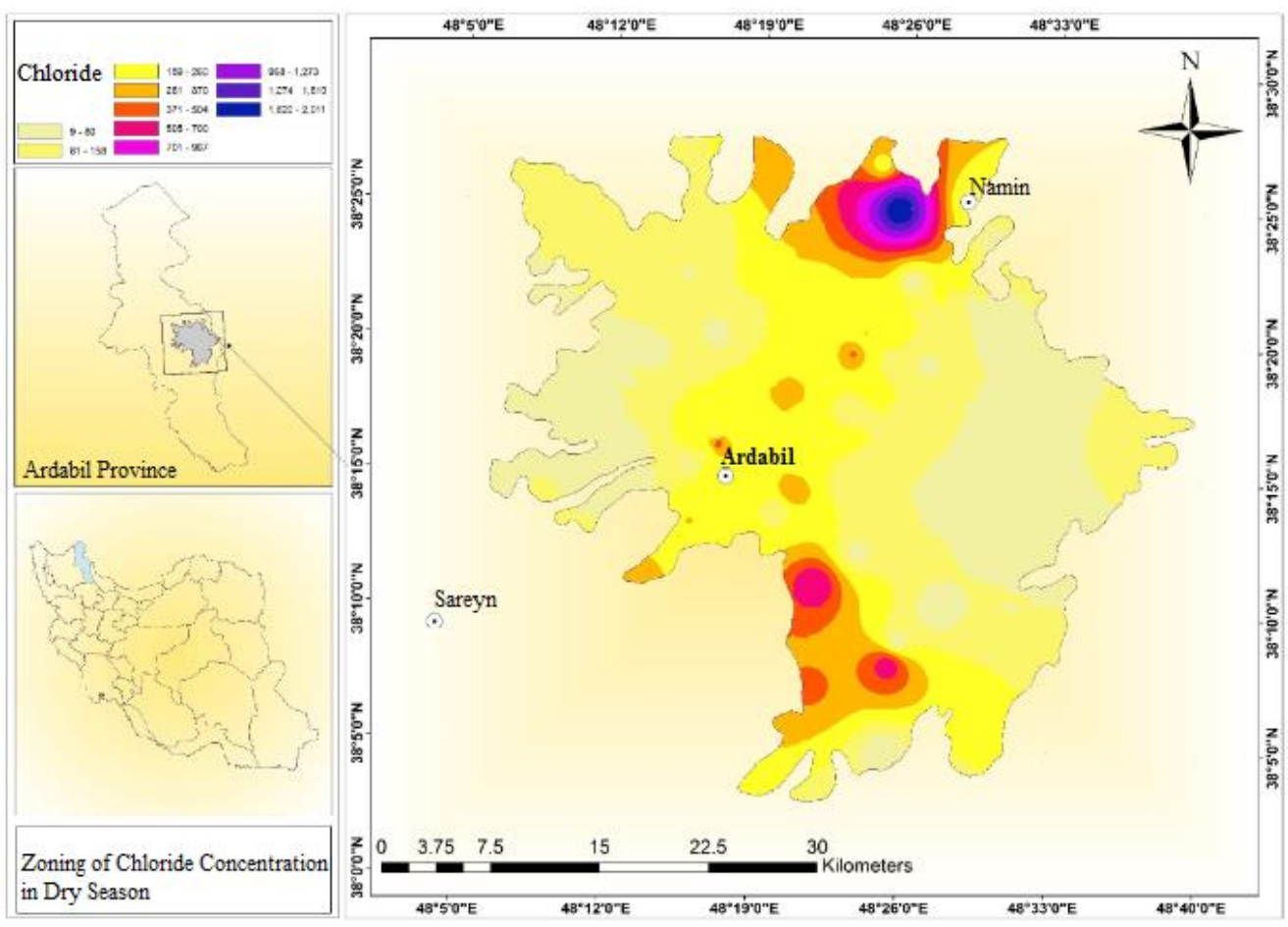

Figure 9. Chloride distribution map in study area (dry season) 
Chloride parameter measurements of all samples from all stations of study area show that in some stations, amount of this parameter has a value higher than the allowable standard limit of drinking water. For example, Chloride has a value several times higher than available drinking water standards in Solout station (Station No:53), which was equal to $2011.7 \mathrm{mg} / \mathrm{l}$.

\subsection{Nitrate of Study Area}

Average, minimum and maximum measured Nitrate parameter of samples from study area in wet and dry seasons are presented in Table 8 .

Table 8. Statistical analysis of Nitrate $(\mathrm{mg} / \mathrm{l})$ concentrations in the study area

\begin{tabular}{cccccccccccc} 
& \multicolumn{3}{c}{ Wet Season } & \multicolumn{3}{c}{ Dry Season } & \multicolumn{3}{c}{ Standard Values } \\
\hline \multirow{2}{*}{ Pollutant } & Min. & Max. & Mean & S.D & Min. & Max. & Mean & S.D & EPA & WHO & EU \\
\hline Nitrate $(\mathrm{mg} / \mathrm{l})$ & 0 & 129.9 & 23.6 & 23.4 & 0 & 143.6 & 39.74 & 33.29 & 10 & - & - \\
\hline
\end{tabular}

Average measured values for Nitrate parameter in wet and dry seasons of the study area are equal to $23.60 \mathrm{mg} / \mathrm{l}$ and $39.74 \mathrm{mg} / \mathrm{l}$, respectively. As seen, Minimum value for Nitrate, which were measured from collected samples, is 0 for wet season, whereas the maximum amount of this parameter is equal to $143.60 \mathrm{mg} / \mathrm{l}$ and related to dry season of Kalkhoran station (Station No:30). Figures 10 and 11. show the Nitrate distribution map of study area.

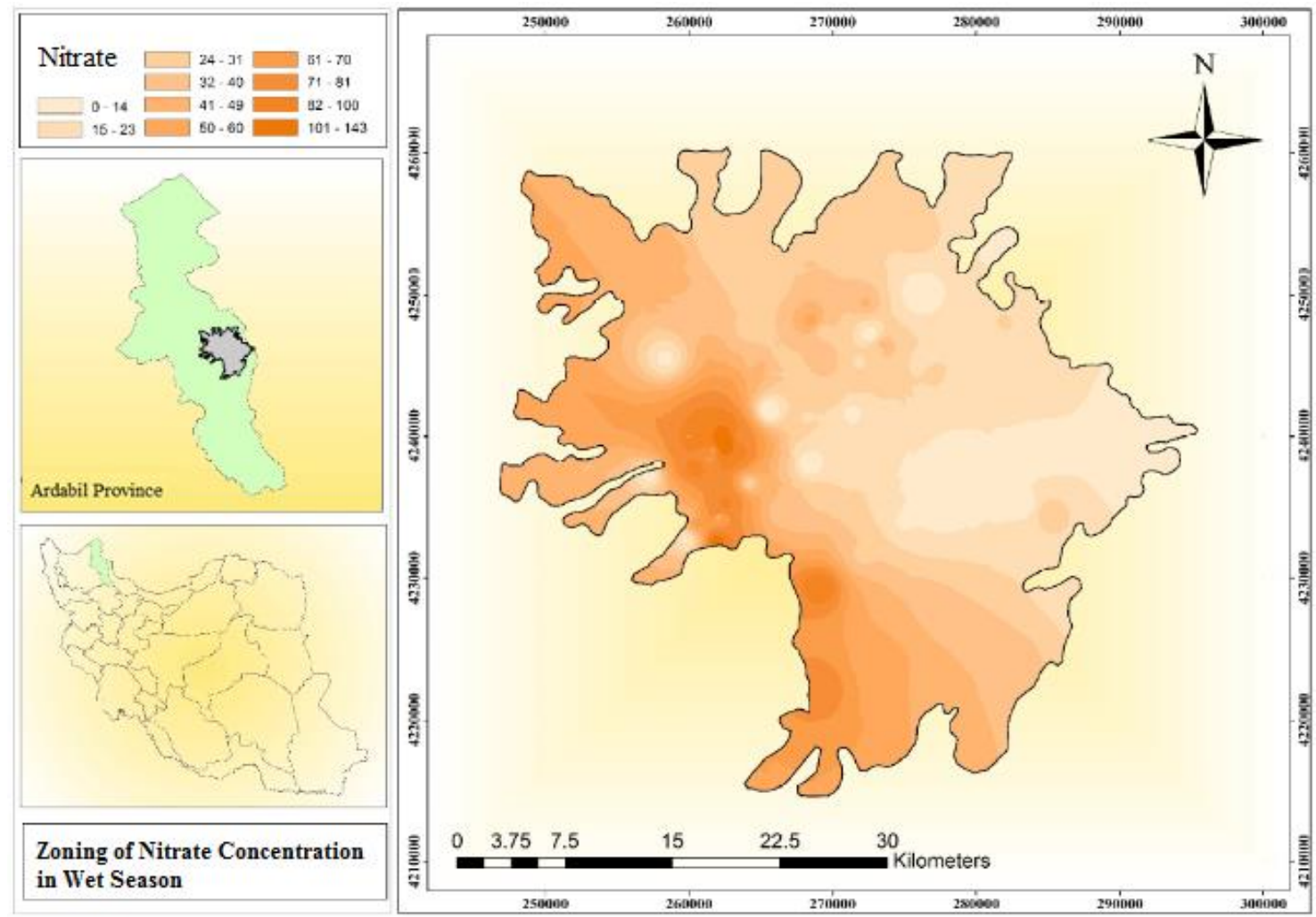

Figure 10. Nitrate distribution map in study area (wet season) 


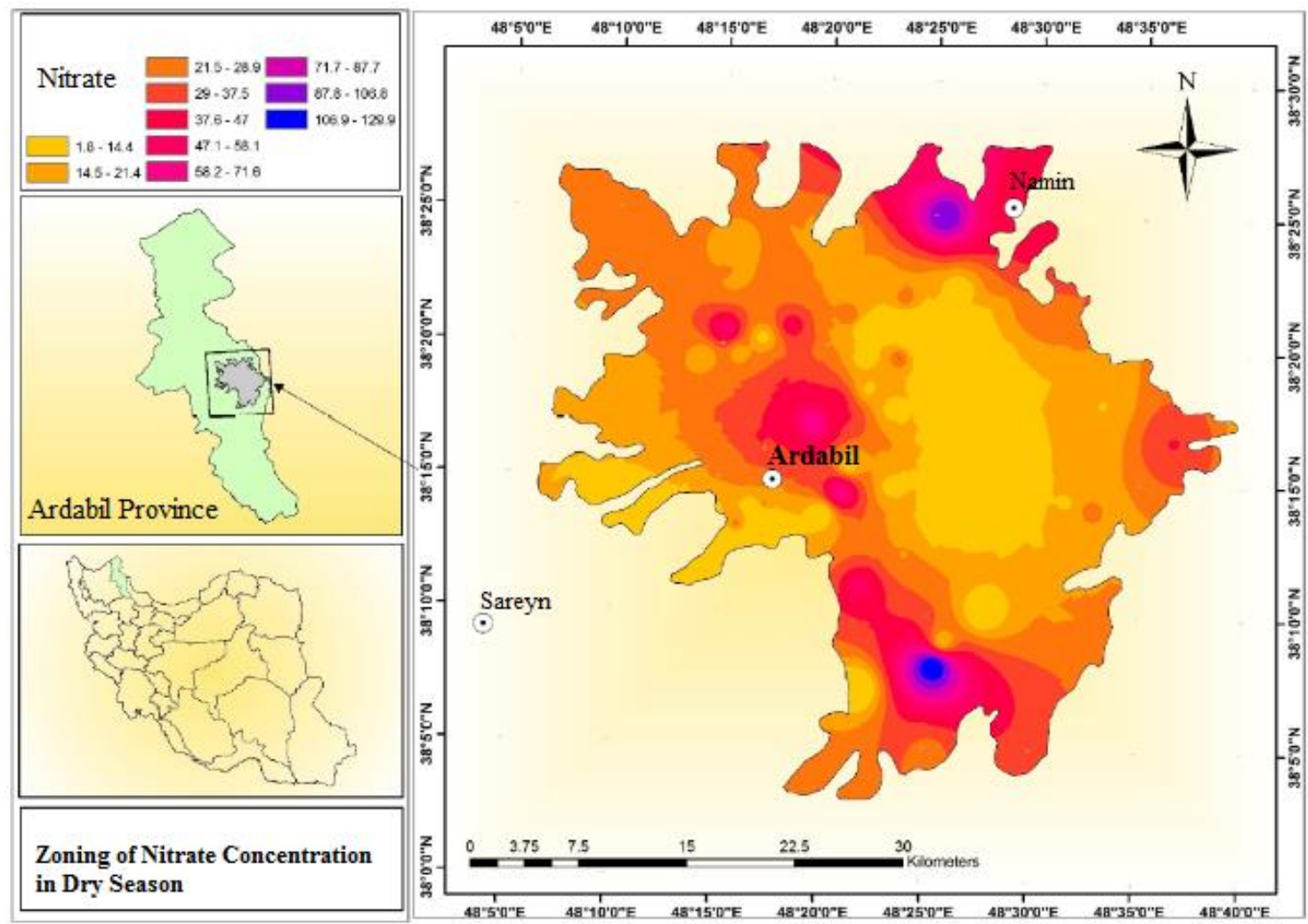

Figure 11. Nitrate distribution map in study area (dry season)

Based on measurements of different samples, which were taken from all selected stations in the study area, it is obvious that the Nitrate parameter amount of water samples exceed the allowable standard limits in some of the stations. Considering the importance of Nitrates in water health, health of people and especially children, special precautions should be taken about this subject. Totally, from the collected data and information, it could be concluded that the concentration of pollutants exceed the standard limit or close to this standard limits in some cases, which require to control and prevention of water resources from pollution.

Table 9. Statistical analysis of all parameters in the study area

\begin{tabular}{cccccccccccc} 
& \multicolumn{4}{c}{ Wet Season } & \multicolumn{4}{c}{ Dry Season } & \multicolumn{3}{c}{ Standard Values } \\
\hline Pollutant & Min. & Max. & Mean & S.D & Min. & Max. & Mean & S.D & EPA & WHO & EU \\
\hline Turbidity (NTU) & 0 & 175 & 5.29 & 24.23 & 0 & 3.15 & 0.071 & 0.412 & $0.5-5$ & 5 & 4 \\
TDS (mg/l) & 92 & 14980 & 1117 & 1541.6 & 148 & 3716 & 1011.93 & 643.65 & 500 & 1000 & - \\
Chloride (mg/l) & 8.9 & 2011.7 & 190 & 253.5 & 20.9 & 1077 & 187.25 & 168.43 & 250 & - & 250 \\
Nitrate (mg/l) & 0 & 129.9 & 23.6 & 23.43 & 0 & 143.6 & 39.74 & 33.29 & 10 & - & - \\
\hline
\end{tabular}

\section{Conclusion}

According to the obtained results from sampling operation and experiments, which were done seasonally in one year for 76 stations of Ardabil basin as case study, the quality zoning (mapping) of aquifer water quality was done for this basin based on NSF quality index. In terms of time, first and second innings of samplings were coincided with Spring and Fall, respectively. According to sampling, experiments and available quality information, aquifer quality maps were prepared annually based on obtained results and related tables and maps were presented. Due to the large number of the stations and samplings, it was avoided to presenting the detailed calculations of NSF index for mentioned parameters in order to decreasing the number of tables. Therefore, overall result of parameter for each station is provided. The quality zoning condition is presented based on all 76 sampling stations for both wet and dry seasons as Tables 10 and 11 , for the study area. As seen in Table 10, from all sampling stations (76 stations) in wet season, 6.58\% (5 stations) have good quality condition, $22.37 \%$ (17 stations) have unsuitable quality condition and the remaining $71.05 \%$ stations (54 stations) have medium quality condition. Due to decreasing in water level and also, because of some unexpected problems about some wells in dry season, the number of sampled wells were reduced to 50 wells. It is seen in Table 11 . that from all sampling stations (50 stations) in dry season, 4\% (2 stations) have good quality condition, $32 \%$ (16 stations) have 
unsuitable quality condition and 64\% (32 stations) have medium quality condition. Following points must be noted:

a) If the water quality is in the excellent condition limit, it is acceptable for any uses without any filtration and refinement process.

b) If it has good quality condition, the pretreatment is required before use.

c) If it is in the medium quality condition limit, it needs the conventional treatment.

d) If it is in the unsuitable quality condition, it needs the advanced treatment.

e) If the water resource has very unsuitable condition, it is unusable for any uses (especially for drinking).

Obtained results show that the Ardabil aquifer is in medium water quality condition and the conventional treatment is required in the present situation.

Table 10. Classification of sampling stations based on quality zoning results in wet season

\begin{tabular}{|c|c|c|c|c|c|c|c|c|c|c|c|}
\hline No. & $\begin{array}{c}\text { Station } \\
\text { No. }\end{array}$ & WQI & Quality & No. & $\begin{array}{c}\text { Station } \\
\text { No. }\end{array}$ & WQI & Quality & No. & $\begin{array}{c}\text { Station } \\
\text { No. }\end{array}$ & WQI & Quality \\
\hline 1 & 64 & 56.6 & Medium & 26 & 28 & 61.1 & Medium & 51 & 33 & 52.86 & Medium \\
\hline 2 & 63 & 59.18 & Medium & 27 & 29 & 41.64 & Unsuitable & 52 & 35 & 54.9 & Medium \\
\hline 3 & 52 & 60.43 & Medium & 28 & 68 & 52.12 & Medium & 53 & 37 & 59.54 & Medium \\
\hline 4 & 66 & 62.27 & Medium & 29 & 75 & 53.2 & Medium & 54 & 38 & 66.17 & Medium \\
\hline 5 & 36 & 56.77 & Medium & 30 & 8 & 67.69 & Medium & 55 & 39 & 61.22 & Medium \\
\hline 6 & 49 & 50.06 & Medium & 31 & 30 & 62.15 & Medium & 56 & 40 & 50.67 & Medium \\
\hline 7 & 42 & 52.6 & Medium & 32 & 27 & 52.82 & Medium & 57 & 41 & 62.95 & Medium \\
\hline 8 & 44 & 54.06 & Medium & 33 & 48 & 53.98 & Medium & 58 & 1 & 49.9 & Unsuitable \\
\hline 9 & 46 & 50.33 & Medium & 34 & 50 & 49.5 & Unsuitable & 59 & 62 & 48.18 & Unsuitable \\
\hline 10 & 26 & 34 & Unsuitable & 35 & 18 & 66.54 & Medium & 60 & 76 & 48.65 & Unsuitable \\
\hline 11 & 24 & 53.22 & Medium & 36 & 31 & 54.12 & Medium & 61 & 10 & 66.21 & Medium \\
\hline 12 & 20 & 69.19 & Medium & 37 & 51 & 65.39 & Medium & 62 & 53 & 49.8 & Unsuitable \\
\hline 13 & 9 & 55.48 & Medium & 38 & 43 & 65.56 & Medium & 63 & 55 & 25.6 & Unsuitable \\
\hline 14 & 61 & 55.21 & Medium & 39 & 45 & 58.52 & Medium & 64 & 54 & 53.99 & Medium \\
\hline 15 & 25 & 71.87 & Good & 40 & 59 & 61.14 & Medium & 65 & 56 & 56.23 & Medium \\
\hline 16 & 19 & 72.57 & Good & 41 & 11 & 61.87 & Medium & 66 & 57 & 60.09 & Medium \\
\hline 17 & 65 & 57.77 & Medium & 42 & 12 & 46.61 & Unsuitable & 67 & 60 & 43.31 & Unsuitable \\
\hline 18 & 23 & 46.99 & Unsuitable & 43 & 13 & 63.48 & Medium & 68 & 58 & 70 & Good \\
\hline 19 & 4 & 55.46 & Medium & 44 & 15 & 56.16 & Medium & 69 & 3 & 65.34 & Medium \\
\hline 20 & 22 & 60.56 & Medium & 45 & 16 & 51.68 & Medium & 70 & 7 & 59.85 & Medium \\
\hline 21 & 32 & 71.69 & Good & 46 & 67 & 50.98 & Medium & 71 & 69 & 48.09 & Unsuitable \\
\hline 22 & 5 & 67.32 & Medium & 47 & 14 & 52.78 & Medium & 72 & 70 & 54.68 & Medium \\
\hline 23 & 34 & 68.9 & Medium & 48 & 17 & 47.28 & Unsuitable & 73 & 71 & 38.35 & Unsuitable \\
\hline 24 & 21 & 76.91 & Good & 49 & 2 & 67.83 & Medium & 74 & 72 & 35.21 & Unsuitable \\
\hline \multirow[t]{2}{*}{25} & 47 & 45.63 & Unsuitable & 50 & 6 & 52.59 & Medium & 75 & 73 & 39.13 & Unsuitable \\
\hline & & & & & & & & 76 & 74 & 53.64 & Medium \\
\hline
\end{tabular}

Table 11. Classification of sampling stations based on quality zoning results in dry season

\begin{tabular}{cccccccccc}
\hline No. & $\begin{array}{c}\text { Station } \\
\text { No. }\end{array}$ & WQI & Quality & No. & $\begin{array}{c}\text { Station } \\
\text { No. }\end{array}$ & WQI & Quality & No. & $\begin{array}{c}\text { Station } \\
\text { No. }\end{array}$ \\
\hline
\end{tabular}




\begin{tabular}{|c|c|c|c|c|c|c|c|c|c|c|c|}
\hline 1 & 64 & 52 & Medium & 18 & 19 & 58.17 & Medium & 35 & 48 & 55.14 & Medium \\
\hline 2 & 63 & 62.5 & Medium & 19 & 65 & 48.23 & Unsuitable & 36 & 50 & 58.39 & Medium \\
\hline 3 & 52 & 49.63 & Unsuitable & 20 & 23 & 43.73 & Unsuitable & 37 & 18 & 56.69 & Medium \\
\hline 4 & 66 & 60.33 & Medium & 21 & 4 & 58.58 & Medium & 38 & 31 & 54.66 & Medium \\
\hline 5 & 36 & 64.12 & Medium & 22 & 22 & 40.7 & Unsuitable & 39 & 51 & 71 & Good \\
\hline 6 & 49 & 46.47 & Unsuitable & 23 & 32 & 63.81 & Medium & 40 & 43 & 61.5 & Medium \\
\hline 7 & 42 & 58.15 & Medium & 24 & 5 & 69.2 & Medium & 41 & 45 & 69.45 & Medium \\
\hline 8 & 44 & 55.99 & Medium & 25 & 34 & 68.72 & Medium & 42 & 11 & 65.66 & Medium \\
\hline 9 & 1 & 58.95 & Medium & 26 & 21 & 70.27 & Good & 43 & 12 & 40.97 & Unsuitable \\
\hline 10 & 46 & 42.49 & Unsuitable & 27 & 47 & 52.67 & Medium & 44 & 13 & 36.37 & Unsuitable \\
\hline 11 & 26 & 43.9 & Unsuitable & 28 & 28 & 55.28 & Medium & 45 & 67 & 47.43 & Unsuitable \\
\hline 12 & 24 & 44.86 & Unsuitable & 29 & 29 & 53.51 & Medium & 46 & 14 & 35.31 & Unsuitable \\
\hline 13 & 20 & 63.24 & Medium & 30 & 68 & 46.14 & Unsuitable & 47 & 17 & 35.48 & Unsuitable \\
\hline 14 & 9 & 57.73 & Medium & 31 & 75 & 62.06 & Medium & 48 & 53 & 55.35 & Medium \\
\hline 15 & 74 & 56.29 & Medium & 32 & 8 & 55.39 & Medium & 49 & 37 & 64.4 & Medium \\
\hline 16 & 61 & 65.13 & Medium & 33 & 30 & 35.95 & Unsuitable & 50 & 56 & 58.2 & Medium \\
\hline 17 & 25 & 62.38 & Medium & 34 & 27 & 34.11 & Unsuitable & & & & \\
\hline
\end{tabular}

\section{References}

[1]Ahmadi E., Aberoumand M.,. Evaluation on Potential of Polutting of Khash Aquifer, East of Iran, Using GIS, Quarterly of Applied Geology, 2009, 5(1).

[2] Alizadeh, Amin. "Principles of applied hydrology." Astan Quds Razavi. Mashhad. 20th issue 808 (2001).

[3] Balakrishnan, P., Abdul Saleem, and N. D. Mallikarjun. "Groundwater quality mapping using geographic information system (GIS): A case study of Gulbarga City, Karnataka, India." African Journal of Environmental Science and Technology 5, no. 12 (2011): 1069-1084.

[4] Colin, Baird. "Environmental chemistry." USA: Copyright by WH Frreman and Company (1995): 310-311.

[5] Asghari Moghadam A., javanmard Z., Vadiati M., Najib M.,. Evaluating the Quality of Mehraban Plain Groundwater Resources Using GQI and FGQI Methods. Journal of Hydrogeomorphology. Issue1, Vol.2, (2015): 79-98.

[6] Darvishzadeh, Ali. "Geology of Iran." Neda Publication, Tehran (1991): 1-901.

[7] Asadi, Parisa, Behzad Ataie-Ashtiani, and Aliasghar Beheshti. "Vulnerability assessment of urban groundwater resources to nitrate: the case study of Mashhad, Iran." Environmental Earth Sciences 76, no. 1 (2017): 41.

[8] Environmental Protection Organization of Iran, Study of Prevention, Control and Reduction of Pollution in Ardabil Aquifer, 2010.

[9] Fritch, T. G., C. L. McKnight, J. C. Yelderman Jr, S. I. Dworkin, and J. G. Arnold. "A predictive modeling approach to assessing the groundwater pollution susceptibility of the Paluxy Aquifer, Central Texas, using a geographic information system." Environmental Geology 39, no. 9 (2000): 1063-1069.

[10] Gharbia, Abdalkarim S., Salem S. Gharbia, Thaer Abushbak, Hisham Wafi, Adnan Aish, Martina Zelenakova, and Francesco Pilla. "Groundwater Quality Evaluation Using GIS Based Geostatistical Algorithms." Journal of Geoscience and Environment Protection 4, no. 02 (2016): 89.

[11] Wagner, Richard J., Robert W. Boulger Jr, Carolyn J. Oblinger, and Brett A. Smith. Guidelines and standard procedures for continuous water-quality monitors: station operation, record computation, and data reporting. No. 1-D3. 2006.

[12] Haller L., Mc Carthy P., O’Brien T., Riehle J., Stuhldreher T., Nitrate Pollution of Groundwater. Journal of Environmental Quality, 22, (1996): P:646-656.

[13] Jahanshahi A., Rouhimogaddam E., Dehvari E., Evaluation of Groundwater Water Quality Parameters Using GIS: A Case Study on Babak City Aquifer. Water and Soil Sciences, 2(24), (2014): 183-197. 
[14] Jha, Dilip Kumar, Marimuthu Prashanthi Devi, Rajendran Vidyalakshmi, Balan Brindha, Nambali Valsalan Vinithkumar, and Ramalingam Kirubagaran. "Water quality assessment using water quality index and geographical information system methods in the coastal waters of Andaman Sea, India." Marine pollution bulletin 100, no. 1 (2015): 555-561.

[15] Krishnaraj, S., S. Kumar, and K. P. Elango. "Spatial analysis of groundwater quality using geographic information system-a case study." IOSR Journal of Environmental Science, Toxicology and Food Technology 9, no. 2 (2015): 1-6.

[16] Mahalingam, B. "Assessment of Groundwater Quality Using GIS Techniques: A Case Study of Mysore City." International Journal of Engineering and Innovative Technology (IJEIT) (2014): 117-122.

[17] Mendes, Maria Paula, and Luís Ribeiro. "Nitrate probability mapping in the northern aquifer alluvial system of the river Tagus (Portugal) using Disjunctive Kriging." Science of the total environment 408, no. 5 (2010): 1021-1034.

[18] Meals, Donald W., Steven A. Dressing, and Thomas E. Davenport. "Lag time in water quality response to best management practices: a review." Journal of environmental quality 39, no. 1 (2010): 85-96.

[19] Nas, Bilgehan, and Ali Berktay. "Groundwater quality mapping in urban groundwater using GIS." Environmental monitoring and assessment 160, no. 1 (2010): 215-227.

[20] Ouyang, Ying. "Evaluation of river water quality monitoring stations by principal component analysis." Water research 39 , no. 12 (2005): 2621-2635.

[21] Remesan, Renji, and R. K. Panda. "Groundwater quality mapping using GIS: A study from India's Kapgari watershed." Environmental Quality Management 16, no. 3 (2007): 41-60.

[22] Subramani, T., S. Krishnan, and P. K. Kumaresan. "Study of groundwater quality with GIS application for Coonoor taluk in Nilgiri district." International Journal of Modern Engineering Research 2, no. 3 (2012): 596-92.

[23] Mynar Babu P., Jai Sankar G., Sreenivasulu V., Harikrishna K.,. Hydrochemical Analysis and Evaluation of Groundwater Quality in Part of Krishna District, Andhra Pradesh - Using Remotesensing and GIS Techniques. International Journal of Engineering Research, Vol.3, Issue:8, (2014): 476-481, ISSN:2319-6890.

[24] Edition, Fourth. "Guidelines for drinking-water quality." WHO chronicle 38 (2011): 104-8.

[25] Yang, Xiaoying, and Wei Jin. "GIS-based spatial regression and prediction of water quality in river networks: a case study in Iowa." Journal of Environmental Management 91, no. 10 (2010): 1943-1951.

[26] Zhou, Zaiming, Guanghui Zhang, Mingjiang Yan, and Jinzhe Wang. "Spatial variability of the shallow groundwater level and its chemistry characteristics in the low plain around the Bohai Sea, North China." Environmental monitoring and assessment 184, no. 6 (2012): 3697-3710. 